Research

\title{
Ecological risk of heavy metal in agricultural soil and transfer to rice grains
}

\author{
Upoma Mahmud ${ }^{1} \cdot$ Md. Tareq Bin Salam¹ $\cdot$ Abu Shamim Khan ${ }^{2} \cdot$ Md. Mizanur Rahman²
}

Received: 11 December 2020 / Accepted: 19 March 2021

(c) The Author(s) 2021 OPEN

\begin{abstract}
Higher accumulation of heavy metals in food grains is one of the leading problems for carcinogenic effects in the body. That's why; scientists have taken this problem as a potential indicator for ensuring safe food. The present study was carried out to assess the ecological risk of heavy metals such as nickel, copper, arsenic, lead, and manganese in agricultural soil and transfer status to rice grain. Soil samples were collected from four agricultural fields at different times in the Dumuria Upazila under Khulna district in Bangladesh. Heavy metal concentration in soil extracts, irrigation water samples, and grain samples was determined by Atomic Absorption Spectrometer. Average metal concentrations in soil were calculated and compared with the reference value in soil. In most cases, heavy metals in agricultural soil (Ni: $61.73-94.52 \mathrm{mg} / \mathrm{kg}$; Cu: 23.33-37.5 mg/kg; As: 7.53-19.63 mg/kg; Pb: 15.17-29.19 mg/kg; Mn:322.98-478.45 mg/kg) were greater than the reference soil (Ni: 13.08-24.55 mg/kg; Cu: 10.35-13.28 mg/kg; As: $1.87-4.61$ mg/kg; Pb: 4.88-8.27 mg/kg; Mn: 52.17-74.3 mg/ $\mathrm{kg})$. Overall risk index stated that the examined soils were at moderate risk of contamination. Transfer Factor of arsenic $(0.018-0.032 \mathrm{mg} / \mathrm{kg})$ and manganese $(0.059-0.155 \mathrm{mg} / \mathrm{kg})$ was higher from soil to rice grain. On the other hand, transfer factor of lead was found negligible that is a good sign of improvement. The findings of the study will be good documentation for planning, risk assessment, and decision-making by environmental managers in this region.
\end{abstract}

Keywords Risk index of heavy metal · Safe limit · Contamination · Rice grain

\section{Introduction}

Heavy metals are ubiquitous in the environment, as a result of both natural and anthropogenic activities, and humans are exposed to them through various pathways [1]. Disposal of solid waste, different paints, and gasoline, agrochemical inputs like fertilizer, manures, residues, and human activities are the main cause for heavy metal accumulation in soil and increase heavy uptake through food consumption those grown on the contaminated area. Heavy metal load in soil and food crops is now taken into research consideration in the scientific world due to the potential impact of human health risk. Accumulation of heavy metals in agricultural soils has taken consideration worldwide due to its harmful effects in soil ecological functions. Heavy metals are directly ingested through food grain and seriously damage human health $[2,3]$. Many studies have been carried out in Bangladeshi soil to assess the heavy metal status in soil. Islam et al. [4] conducted a study to assess the ecological risk of heavy metals in different land uses in Bangladesh and found moderate to very high ecological risk of heavy metals. Salam et al. [5] carried another research in the tobacco field in northern Bangladesh to measure the ecological risk of heavy metals and concluded that tobacco cultivation increases the vulnerability of heavy

Md. Tareq Bin Salam, tareqss@swe.ku.ac.bd | 2 Soil, Water and Environment Discipline, Khulna University, Khulna, Bangladesh. ${ }^{2}$ Asia Arsenic Network, Jashore, Bangladesh.

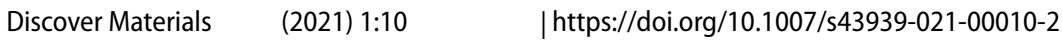

Published online: 05 April 2021 
metal accumulation risk in soil. So, soil and environmental scientists have taken this issue as a big threat for ensuring safe food in the future.

Heavy metal accumulation in plants depends upon plant species and the efficiency of different plants in absorbing metals is evaluated by either plant uptake or soil to plant transfer factors of the metals [6]. In Bangladesh, rice is the main staple food and almost all people are primarily dependant on rice [7]. So, the safe production of rice is the prerequisite in Bangladesh. Rice plants usually uptake heavy metals readily and accumulates in a considerable amount in rice grains [8]. Heavy metals commonly found at contaminated sites and that are lead (Pb), chromium (Cr), arsenic (As), zinc ( $\mathrm{Zn}$ ), cadmium (Cd), copper $(\mathrm{Cu})$, mercury $(\mathrm{Hg})$, and nickel (Ni). Heavy metal contamination of soil may pose risks and hazards to humans and the ecosystem through direct ingestion or contact with contaminated soil, the food chain (soil-plant-human or soil-plant-animal-human), drinking of contaminated groundwater, reduction in food quality (safety and marketability) via phytotoxicity, reduction in land usability for agricultural production causing food insecurity, and land tenure problems [9]. Risk index (RI) is an indicator used to assess the degree of environmental risk caused by a concentration of heavy metals both in water and air, as well as in soil and soil pollution index (SPI) is a single pollution index of heavy metal using reference data $[10,11]$. Reference data is a special subset of master data that is used for classification throughout the entire experiment [11]. In Bangladesh, there is no established tolerable/safe limit available for heavy metals in soil and crops. Therefore, the levels of heavy metals found in different sources of the present study were compared with the prescribed safe limit provided by World Health Organization [12] and other authors [13].

The soil in Bangladesh is highly variable and the concentration of mineral elements such as zinc, copper, and nickel vary drastically from one place to another [14]. Therefore, the research was conducted in Dumuria Upazila (sub-district) under Khulna district to find out the exposure and risk of different heavy metals in agricultural surface soil and its potential transfer to rice grain. Dumuria is situated in south-western part of the country and traditionally enriched with rice cultivation due to its high soil productivity. High application of agricultural inputs causes the major destruction of soils here that accumulates a large number of heavy metals in soil [15]. Due to the accumulation of heavy metals, there is a chance to accumulate the heavy metals in rice grain that may lead the potentially life-threatening diseases $[16,17]$. However, the study has opened a new dimension about assessing heavy metal status in agricultural soil and rice grain that will help to make decisions for treating the soil in future land protection.

\section{Materials and methods}

\subsection{Sample collection and processing}

The samples were collected from four sampling sites in Dumuria sub-district under Khulna district in Bangladesh (Fig. 1). The sampling sites were in Gutudia $\left(22^{\circ} 47^{\prime} \mathrm{N}, 89^{\circ} 27^{\prime} \mathrm{E}\right)$, Mechaghona $\left(22^{\circ} 48^{\prime} \mathrm{N}, 89^{\circ} 24^{\prime} \mathrm{E}\right)$, Dhamalia $\left(22^{\circ} 96^{\prime} \mathrm{N}, 89^{\circ} 37^{\prime} \mathrm{E}\right)$, and Koiya $\left(22^{\circ} 46^{\prime} \mathrm{N}, 89^{\circ} 31^{\prime} \mathrm{E}\right)$. The average temperature of the area is $28^{\circ} \mathrm{C}$ and the land type is medium-high. Soil texture is mostly clayey loam and the average rainfall per annum is $215 \mathrm{~mm}$ [18]. Surface soils ( $0-15 \mathrm{~cm}$ depth) were collected from twelve agricultural fields of four sampling sites before rice cultivation and after harvesting of rice plants. From each field, ten samples were taken and the total number of samples was 120 . Uncultivated soil was treated as reference soils for each sampling site and irrigation water samples were collected in good quality screw capped high density pre sterilized polypropylene bottles, each of 1 lt capacity and labelled properly. Grain samples were collected at $14 \%$ moisture level after harvesting (at the matured stage). The collected samples were processed in the laboratory of soil, Water and Environment discipline and kept air drying. Then soil samples were grinded and passed through a $2 \mathrm{~mm}$ sieve. Soil samples will be kept in the laboratory under cool conditions $\left(4{ }^{\circ} \mathrm{C}\right)$ and stored at $-20^{\circ} \mathrm{C}$ until analyzed.

\subsection{Samples analysis}

Organic carbon content in soil was analysed by Walkley-Black wet oxidation method [19]. Soil pH was determined in distilled water using the Jeneway pH meter (model no. 3510) with a water ratio of 1:5 [20] Soil electrical conductivity (EC) was measured by using Jeneway EC meter (model no. 4510) with a ratio of 1:2.5 [20]. Heavy metal concentration in soil extracts, irrigation water samples, and grain samples was determined by atomic absorption spectrometer after acid digestion $\left(\mathrm{HNO}_{3}+\mathrm{HCl}\right.$ at 3:1) [21]. Twenty milliliters of the acid mixture were used for each 1 gm sample digested and the temperature of the mixture was raised to $150^{\circ} \mathrm{C}$ on heating digestion block for two and half hours. Then the digest was cooled and filtered by using Whatman filter 42 and volume $25 \mathrm{ml}$ by using distilled water. The blank sample was run by 
Fig. 1 Map of the study area

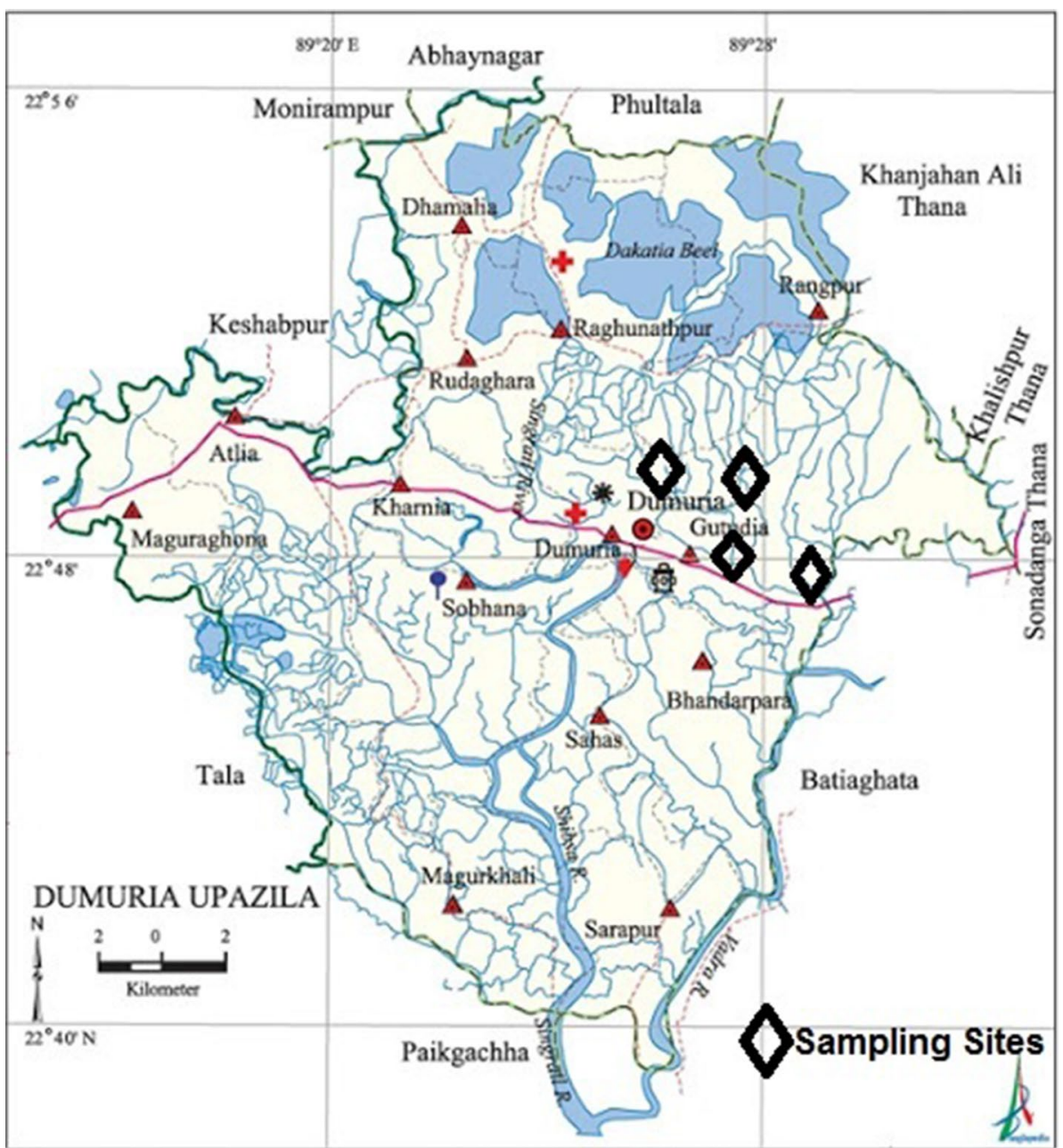

following a similar procedure. Then, the extract was passed in different wavelengths (Mn: $279.5 \mathrm{~nm}, \mathrm{Cu}: 324.8 \mathrm{~nm}$, As: $193.7 \mathrm{~nm}$ Ni: $341.5 \mathrm{~nm}, \mathrm{~Pb}: 283.3 \mathrm{~nm}$ ) in atomic absorption spectrophotometer for detecting different metal.

\subsection{Measurement of soil pollution (SPI) and ecological risk index (RI)}

Soil pollution index (SPI) was measured by using the following Eq. (1):

$$
S P I=\frac{\mathrm{Ci}}{C b i},
$$

where, SPI is the soil pollution index, $\mathrm{Ci}$ is the concentration of the ith heavy metal in the soil, and $\mathrm{Cbi}$ is its reference soil value. SPI can be classified into five categories: unpolluted $(\mathrm{SPI} \leq 1)$, slightly polluted $(1<\mathrm{SPI} \leq 2)$, mildly polluted $(2<\mathrm{SPI} \leq 3)$, moderately polluted $(3<\mathrm{SPI} \leq 5)$, and highly polluted $(\mathrm{SPI}>5)[22]$.

The ecological risk index (RI) was calculated by using the most accepting following formula to assess the ecological risk (ER) of heavy metals [23]:

$$
\begin{gathered}
R I=\sum_{i=1}^{n} \mathrm{ERi}, \\
E R i=T i \times\left(\frac{\mathrm{Ci}}{C b i}\right),
\end{gathered}
$$


Table 1 Classification of potential ecological risk index [25]

\begin{tabular}{llll}
\hline ER value & $\begin{array}{l}\text { Grade of ecological risk of } \\
\text { single metal }\end{array}$ & $\mathrm{RI}$ value & $\begin{array}{l}\text { Grade of potential eco- } \\
\text { logical risk of the environ- } \\
\text { ment }\end{array}$ \\
\hline $\mathrm{ER}<40$ & Low risk & $\mathrm{Rl}<112.5$ & Low risk \\
$40 \leq \mathrm{ER}<80$ & Moderate risk & $112.5 \leq \mathrm{RI}<225$ & Moderate risk \\
$80 \leq \mathrm{ER}<160$ & Considerable risk & $225 \leq \mathrm{Rl}<450$ & Considerable risk \\
$160 \leq \mathrm{ER}<320$ & High risk & $\mathrm{RI}>450$ & Very High risk \\
$\mathrm{ER} \geq 320$ & Very high risk & - & - \\
\hline
\end{tabular}

Unpolluted $(\mathrm{SPI} \leq 1)$, slightly polluted $(1<\mathrm{SPI} \leq 2)$, mildly polluted $(2<\mathrm{SPI} \leq 3)$, moderately polluted $(3<\mathrm{SPI} \leq 5)$, and highly polluted (SPI $>5)[25]$

where, ERi is the ecological risk index for the heavy metal $i$, and $\mathrm{Ti}$ is the toxicity response coefficient for the metal $\mathrm{i}$. The toxic response factors for $\mathrm{Mn}, \mathrm{Cu}, \mathrm{As}, \mathrm{Ni}$, and $\mathrm{Pb}$ are 10, 5, 10, 6, and 5, respectively [24]. According to Xia et al. [25], RI standard grading is given in Table 1.

\subsection{Heavy metal's transfer factor (TF) analysis}

Transfer factor (TF) denotes the potential transfer of metals from soil to plants. It is usually used to evaluate the ability of plants to uptake metals from soil. Transfer factor of each heavy metal was analyzed by using the following formula [26].

$$
\mathrm{TF}=\frac{\text { Metal load in crop grain }}{\text { Metal load in soil after harvesting }} .
$$

\subsection{Statistical data analysis}

The data for the soil samples were subjected to analysis of variance (ANOVA) and probability test ( $p$ value) using SPSS 24.0 Software to ascertain the accuracy and validity of the results from the study area. To identify the relationship among elements, a Pearson bivariate correlation was used. MS-Excel 2007 package was used for doing all calculations and drawing graphs.

Table 2 Soil pH, EC and organic carbon content at different sampling sites

\begin{tabular}{lllll}
\hline Sampling Sites & Parameters & $\mathrm{pH}$ & $\mathrm{EC}(\mathrm{dS} / \mathrm{m})$ & SOC (\%) \\
\hline Gutudia & Soil before cultivation & $7.47 \pm 0.02 \mathrm{a}$ & $4.40 \pm 0.01 \mathrm{a}$ & $0.93 \pm 0.05 \mathrm{a}$ \\
& Soil after harvesting & $7.76 \pm 0.02 \mathrm{a}$ & $4.20 \pm 0.04 \mathrm{a}$ & $0.61 \pm 0.03 \mathrm{~b}$ \\
& Reference soil & $7.04 \pm 0.03 \mathrm{~b}$ & $4.24 \pm 0.01 \mathrm{a}$ & $0.61 \pm 0.01 \mathrm{~b}$ \\
Mechagona & Soil before cultivation & $7.81 \pm 0.01 \mathrm{a}$ & $4.22 \pm 0.01 \mathrm{a}$ & $0.41 \pm 0.01 \mathrm{~b}$ \\
& Soil after harvesting & $7.62 \pm 0.37 \mathrm{a}$ & $4.28 \pm 0.05 \mathrm{a}$ & $1.15 \pm 0.01 \mathrm{a}$ \\
& Reference soil & $7.93 \pm 0.01 \mathrm{a}$ & $4.23 \pm 0.02 \mathrm{a}$ & $0.44 \pm .08 \mathrm{~b}$ \\
Dhamalia & Soil before cultivation & $7.21 \pm 0.04 \mathrm{~b}$ & $4.24 \pm 0.02 \mathrm{~b}$ & $0.62 \pm 0.02 \mathrm{~b}$ \\
& Soil after harvesting & $7.36 \pm 0.01 \mathrm{a}$ & $4.48 \pm 0.05 \mathrm{a}$ & $0.89 \pm 0.03 \mathrm{a}$ \\
& Reference soil & $7.44 \pm 0.01 \mathrm{a}$ & $4.32 \pm 0.02 \mathrm{a}$ & $0.64 \pm 0.02 \mathrm{~b}$ \\
Koiya & Soil before cultivation & $7.46 \pm 0.01 \mathrm{a}$ & $4.05 \pm 0.02 \mathrm{~b}$ & $0.31 \pm 0.02 \mathrm{~b}$ \\
& Soil after harvesting & $7.64 \pm 0.04 \mathrm{a}$ & $4.14 \pm 0.02 \mathrm{a}$ & $0.78 \pm 0.05 \mathrm{~b}$ \\
& Reference soil & $7.57 \pm 0.02 \mathrm{a}$ & $4.24 \pm 0.01 \mathrm{a}$ & $0.34 \pm 0.01 \mathrm{~b}$ \\
\hline
\end{tabular}


Fig. $2 \mathrm{Ni}(\mathrm{mg} / \mathrm{kg})$ and $\mathrm{Cu}(\mathrm{mg} /$ $\mathrm{kg}$ ) in soil samples
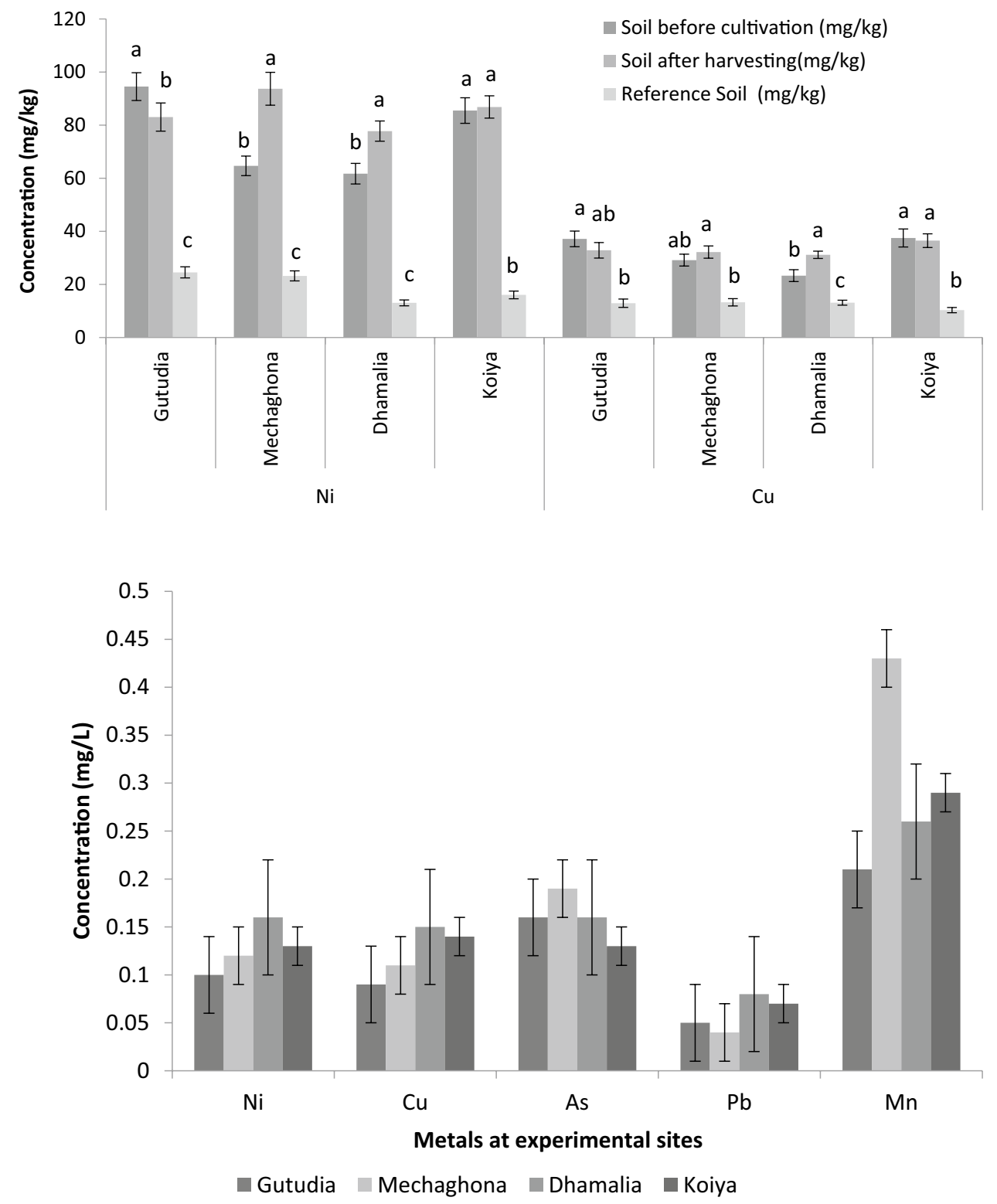

\section{Results}

\subsection{General characteristics of soil in different sampling sites}

Table 2 supplies the information concerning general soil characteristics at different times in the sampling sites, where $\mathrm{pH}$ and EC were almost statistically similar for most of the sampling sites $(p<0.05)$ before cultivation and after harvesting. $\mathrm{pH}$ ranged from 7.04 to 7.93 which indicated almost neutral to alkaline in character and EC ranged from 4.05 to 4.40 $\mathrm{dS} / \mathrm{m}$ that represented the moderate saline soil. However, soil organic carbon (SOC) was comparatively lower in every soil sample and ranged from $0.34 \%$ to $1.15 \%$ but a significant difference was observed among the variables $(p<0.05)$. Soil organic carbon (SOC) is a measureable tool of soil organic matter. A healthy soil should have $5 \%$ of organic matter. SOC controls the physical, chemical and biological behaviour of agricultural soils. In most cases, soil organic carbon was improved after harvesting. 
Fig. 4 As (mg/kg) and $\mathrm{Pb}(\mathrm{mg} /$ $\mathrm{kg}$ ) in soil samples

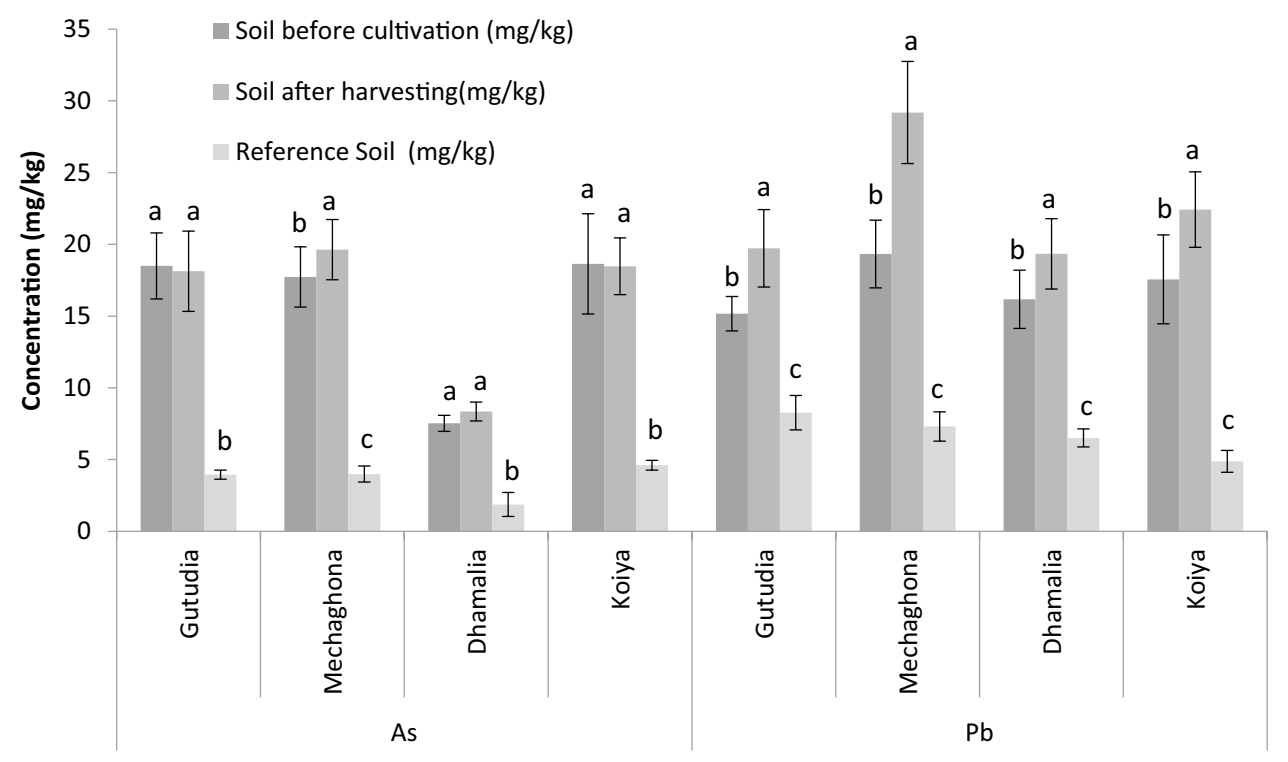

Fig. $5 \mathrm{Mn}(\mathrm{mg} / \mathrm{kg})$ in soil samples

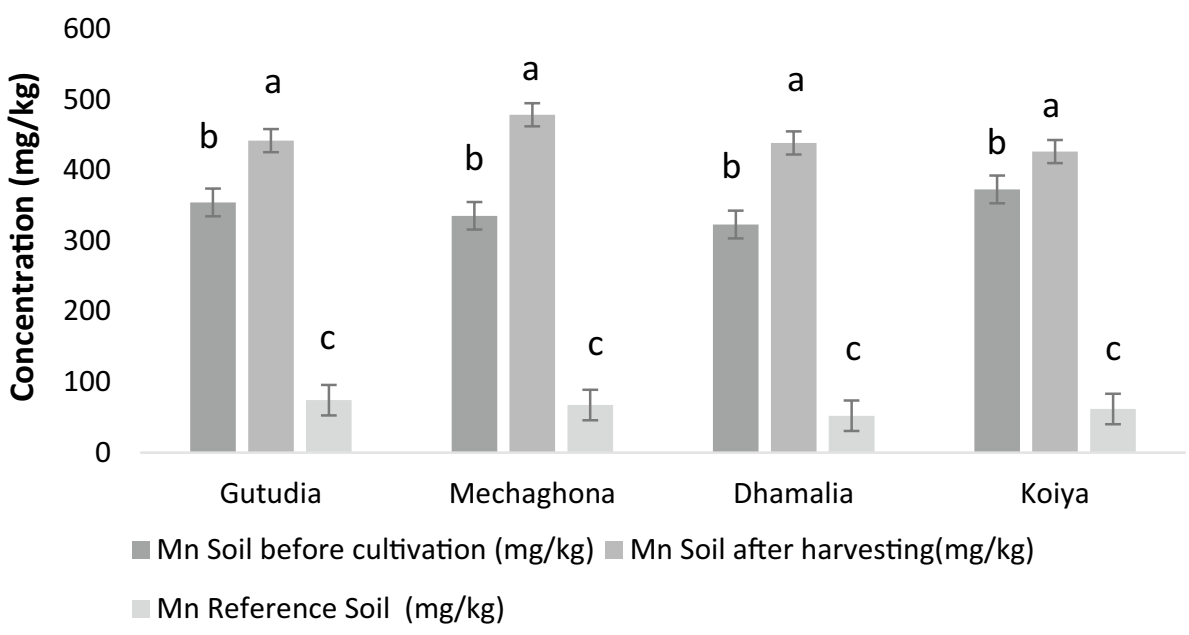

\subsection{Heavy metal analysis}

The highest concentration of $\mathrm{Ni}(94.52 \pm 8.04 \mathrm{mg} / \mathrm{kg})$ was found in Gutudia for the initial soil before cultivation (Fig. 2). On the other hand, in the soil after harvesting, the highest concentration $(93.71 \pm 8.17 \mathrm{mg} / \mathrm{kg}$ ) was observed in Mechaghona and the lowest concentration $(77.76 \pm 2.87 \mathrm{mg} / \mathrm{kg})$ was found in Dhamalia. This might due to irrigation water containing different Ni concentration in different sampling sites (Fig. 3). According to Barałkiewicz and Siepak [27], the solubility of nickel in soils increased with increasing $\mathrm{Ni}$ concentration in irrigation water. The highest concentration of $\mathrm{Cu}$ $(37.5 \pm 4.08 \mathrm{mg} / \mathrm{kg})$ was reported in Koiya for the initial soil before cultivation. The highest concentration was also notified in Koiya $(36.47 \pm 2.17 \mathrm{mg} / \mathrm{kg}$ ) soil after harvesting. This might due to irrigation water containing more Cu concentration in Koiya rather than other sites (Fig. 3). According to the World Health Organization [12], soil containing Cu more than $100 \mathrm{mg} / \mathrm{kg}$ can be exposed to contaminate the soil. But in Bangladesh, no permissible limit has yet been set for Cu in agricultural soil [13]. However, in the investigated areas, irrigated soil loaded more $\mathrm{Ni}$ and $\mathrm{Cu}$ concentration than reference soil which is a matter of rising concern for crop production.

As per Fig. 4, the highest concentration of As $(18.64 \pm 3.5 \mathrm{mg} / \mathrm{kg})$ was seen in Koiya for the initial soil before cultivation, and the soil after harvesting, the highest concentration $(19.63 \pm 2.1 \mathrm{mg} / \mathrm{kg})$ was also noticed in Mechaghona field. This might due to irrigation water containing more As concentration in Mechaghona rather than other sites (Fig. 3). WHO/ FAO [12] reported that soil containing As more than $20 \mathrm{mg} / \mathrm{kg}$ was exposed to contaminate the soil. But in Bangladesh, 
no permissible limit has yet been set for As in agricultural soil [13]. In the investigated areas, most irrigated soils nearly touched the boarder limit of As contamination as well as loaded 5 times greater As than reference soil which could be an emerging problems for future farming. As load might happen due to the use of As contaminated water and Asenriched fertilizers, as well as pesticides in the agricultural land [28, 29]. From Fig. 4, the highest concentration of $\mathrm{Pb}$ $(19.33 \pm 2.36 \mathrm{mg} / \mathrm{kg})$ was found in Mechaghona for the initial soil before cultivation and again,the soil after harvesting, the highest concentration $(29.19 \pm 3.56 \mathrm{mg} / \mathrm{kg})$ was also observed in Mechaghona. According to WHO/FAO [13], soil containing $\mathrm{Pb}$ more than $100 \mathrm{mg} / \mathrm{kg}$ was exposed to contaminate the soil. But in Bangladesh, no permissible limit has yet been set for $\mathrm{Pb}$ in agricultural soil. However, in the study areas, most irrigated soils loaded more $\mathrm{Pb}$ concentration than reference soil revealing a matter of rising concern.

Figure 5 explained that the highest concentration of $\mathrm{Mn}(372 \pm 16.34 \mathrm{mg} / \mathrm{kg})$ was pointed in Koiya for the initial soil before cultivation. However, in the soil after harvesting, the highest concentration $(478.45 \pm 16.33 \mathrm{mg} / \mathrm{kg})$ was reported in Mechaghona. This might due to irrigation water having more Mn concentration $(0.42 \mathrm{mg} / \mathrm{L})$ in Mechaghona rather than other sites (Fig. 3). According to WHO/FAO [13], soil containing Mn more than $2000 \mathrm{mg} / \mathrm{kg}$ can be exposed to contaminate the soil. In Bangladesh, no permissible limit has been established for $\mathrm{Mn}$ in agricultural soil. However, some irrigated soils loaded more $\mathrm{Mn}$ concentration than reference soil which is also a rising concern.

\subsection{Heavy metal status in irrigation water samples}

Figure 3 stated that irrigation water contained the highest amount of $\mathrm{Mn}(0.1-0.4 \mathrm{mg} / \mathrm{L})$ rather than any other metals. According to WHO/FAO [12], Mn content should be less than $0.20 \mathrm{mg} / \mathrm{L}$ for using water in irrigation. Accordingly, irrigation water in Mechaghona sampling sites exceeded the recommended value. Though the contents of $\mathrm{Pb}$ in different sampling sites were not higher $(0.02-0.75 \mathrm{mg} / \mathrm{L})$, Dhamalia and Koiya sampling sites lived in the borderline of risk according to WHO/FAO [12] guideline (0.065 mg/L). On the other hand, Cu values (0.03-0.14 mg/L) exceeded WHO/FAO [12] recommendation value $(0.017 \mathrm{mg} / \mathrm{L})$ in all the sampling sites. In terms of $\mathrm{Ni}$ and $\mathrm{As}$, all the sampling sites represented the optimal values as compared with recommended values by WHO/FAO [12].

\subsection{Pearson correlation coefficient among heavy metals and physiochemical properties of soil}

Pearson correlation coefficient among heavy metals and physicochemical properties of soil are presented in Table 3. Pearson's correlation coefficient is the test statistics that measures the statistical relationship, or association, between two continuous variables. Significant positive correlation was observed between $\mathrm{pH}-\mathrm{As}\left(0.86^{*}\right), \mathrm{pH}-\mathrm{Pb}\left(0.97^{* *}\right), \mathrm{Ni}-\mathrm{As}\left(0.91^{*}\right)$ and $\mathrm{As}-\mathrm{Pb}\left(0.70^{*}\right)$. Also, significant negative correlation was also noticed between pH-EC $\left(-0.89^{*}\right)$, EC-Mn $\left(-0.91^{* *}\right)$, $\mathrm{EC}-\mathrm{Cu}\left(-0.97^{* *}\right)$. This means that $\mathrm{As}$ and $\mathrm{Pb}$ concentrations might increase as increasing $\mathrm{pH}$ as well as $\mathrm{Ni}$ concentration might increase with increasing As content. Similar statement is also true for As-Pb relationship. Other finding is that changing of EC has a negative impact on $\mathrm{Mn}$ and Cu availability. Other's correlations were found to be non-significant which means the concentration of one element may not influence other elements concentrations in the studied area.

Table 3 Correlation among different parameters of soil

\begin{tabular}{lllllllll}
\hline & $\mathrm{pH}$ & $\mathrm{EC}$ & $\mathrm{OC}$ & $\mathrm{Ni}$ & $\mathrm{Cu}$ & $\mathrm{As}$ & $\mathrm{Pb}$ & $\mathrm{Mn}$ \\
\hline $\mathrm{pH}$ & 1 & & & & & & \\
$\mathrm{EC}$ & $-0.89^{*}$ & 1 & & & & & \\
$\mathrm{OC}$ & -0.39 & 0.37 & 1 & & & & \\
$\mathrm{Ni}$ & -0.34 & 0.22 & 0.97 & 1 & & & \\
$\mathrm{Cu}$ & 0.91 & $-0.97^{*}$ & -0.15 & -0.02 & 1 & & \\
$\mathrm{As}$ & $0.86^{*}$ & -0.84 & 0.10 & $0.91^{*}$ & 0.95 & 1 & \\
$\mathrm{~Pb}$ & $0.97^{* *}$ & -0.84 & -0.60 & -0.56 & 0.79 & $0.70^{*}$ & 1 & \\
$\mathrm{Mn}$ & 0.94 & $-0.91^{* *}$ & -0.09 & 0.01 & $0.98^{* *}$ & 0.98 & 0.82 & 1 \\
\hline
\end{tabular}

${ }^{*}$ Correlation is significant at the 0.05 level (2-tailed)

${ }^{* *}$ Correlation is significant at the 0.01 level (2-tailed) 


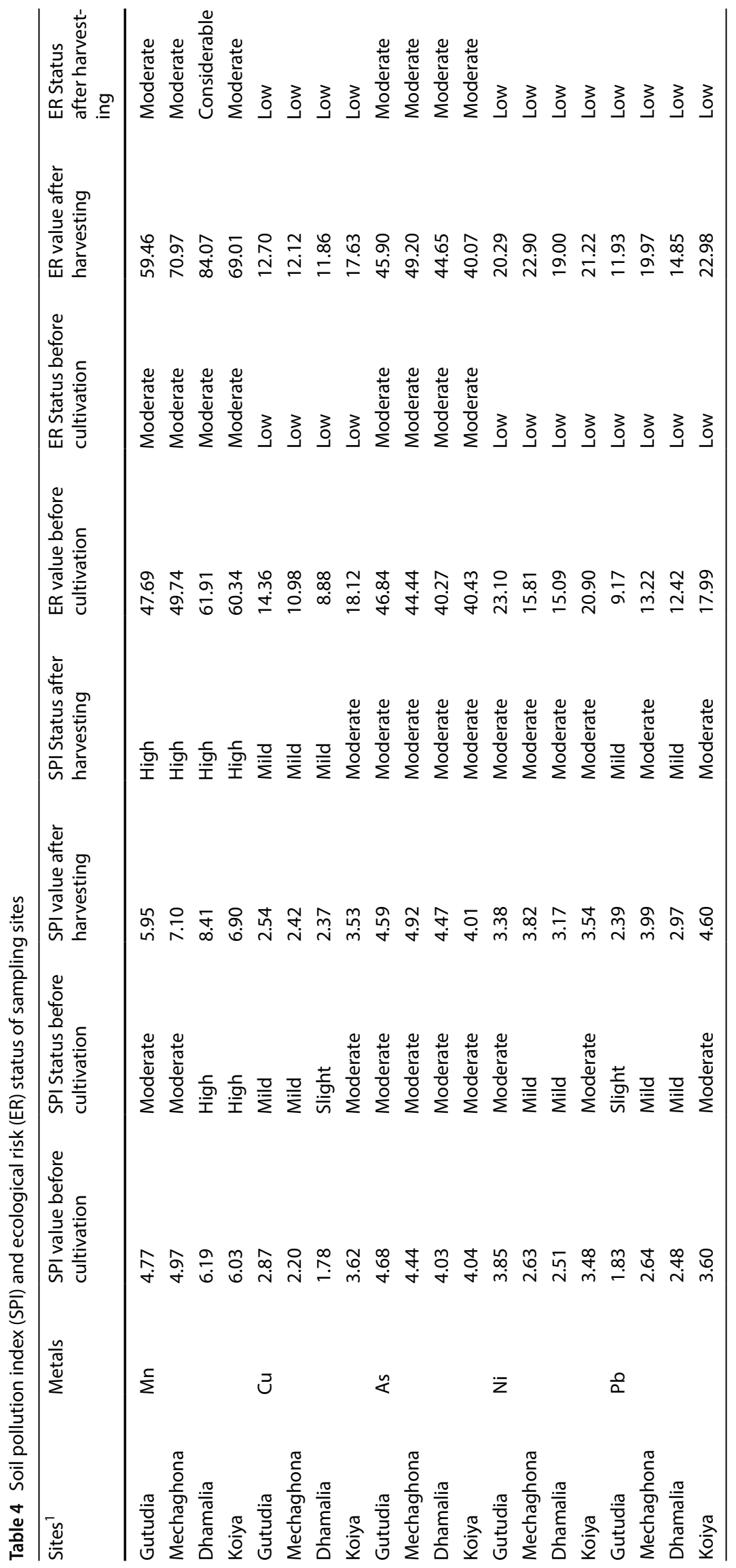


Table 5 Risk status of sampling sites

\begin{tabular}{lllll}
\hline Sites $^{1}$ & $\begin{array}{l}\text { Risk Index value before } \\
\text { cultivation }\end{array}$ & $\begin{array}{l}\text { Risk status before } \\
\text { cultivation }\end{array}$ & $\begin{array}{l}\text { Risk Index value after } \\
\text { harvesting }\end{array}$ & $\begin{array}{l}\text { Risk status } \\
\text { after harvest- } \\
\text { ing }\end{array}$ \\
\hline $\begin{array}{l}\text { Gutudia } \\
\text { Mechaghona }\end{array}$ & 141.16 & Moderate & 150.28 & Moderate \\
Dhamalia & 134.18 & Moderate & 175.16 & Moderate \\
Koiya & 138.56 & Moderate & 174.44 & Moderate \\
\hline
\end{tabular}

Table 6 Heavy metal assessment in grain samples

\begin{tabular}{|c|c|c|c|c|c|c|c|c|c|c|c|c|c|c|c|}
\hline \multirow[t]{2}{*}{ Sampling sites } & \multicolumn{3}{|l|}{ As (mg/kg) } & \multicolumn{3}{|l|}{$\mathrm{Mn}(\mathrm{mg} / \mathrm{kg})$} & \multicolumn{3}{|l|}{$\mathrm{Ni}(\mathrm{mg} / \mathrm{kg})$} & \multicolumn{3}{|l|}{$\mathrm{Pb}(\mathrm{mg} / \mathrm{kg})$} & \multicolumn{3}{|c|}{$\mathrm{Cu}(\mathrm{mg} / \mathrm{kg})$} \\
\hline & Grain & $\mathrm{PL}^{\mathrm{a}}$ & TF & Grain & $P^{a}$ & TF & Grain & $\mathrm{PL}^{\mathrm{b}}$ & TF & Grain & $\mathrm{PL}^{\mathrm{a}}$ & TF & Grain & $\mathrm{PL}^{\mathrm{a}}$ & TF \\
\hline Gutudia & $0.53 \pm 0.05$ & 0.15 & 0.029 & $52.16 \pm 3.12$ & 500 & 0.118 & $5.93 \pm 1.2$ & 67 & 0.071 & $0.08 \pm 0.03$ & 0.3 & 0.004 & $1.32 \pm 0.4$ & 73 & 0.04 \\
\hline Mechghona & $0.36 \pm 0.04$ & & 0.018 & $28.08 \pm 3.9$ & & 0.059 & $6.78 \pm 2.1$ & & 0.072 & $0.06 \pm 0.02$ & & 0.002 & $3.39 \pm 0.8$ & & 0.105 \\
\hline Dhamalia & $0.27 \pm 0.04$ & & 0.032 & $67.98 \pm 3.94$ & & 0.155 & $11.49 \pm 2.4$ & & 0.148 & $0.12 \pm 0.07$ & & 0.006 & $4.25 \pm 0.7$ & & 0.136 \\
\hline Koiya & $0.39 \pm 0.03$ & & 0.021 & $36.95 \pm 4.27$ & & 0.087 & $9.23 \pm 3.4$ & & 0.106 & $0.17 \pm 0.06$ & & 0.008 & $2.67 \pm 0.5$ & & 0.074 \\
\hline
\end{tabular}

TF mean transfer factor

${ }^{\text {a }} \mathrm{PL}=$ Permissible limit recommended by WHO (Chiroma et al. [30])

${ }^{b} \mathrm{PL}=$ Permissible limit recommended by China (Hojsak et al. [31])

\subsection{Soil pollution and risk index of heavy metal assessment}

Soil pollution index (SPI) and ecological risk (ER) status were presented in Table 4. SPI values of Mn before cultivation varied from 4.77 to 6.19 indicating moderate to high soil pollution but SPI values of $\mathrm{Mn}$ after harvesting ranged from 5.95 to 8.41 revealing high soil pollution. ER value of $\mathrm{Mn}$ (84.07) was the highest in Dhamalia soil after harvesting which recommended considerable ecological risk. It was also noticeable that all other sampling sites were presented moderate ecological risk. This might due to irrigation water containing more Mn than other metals. SPI values of Cu before cultivation varied from 1.78 to 3.62 which pointed slightly to moderate soil pollution but SPI values of Cu after harvesting ranged from 2.37 to 3.53 , which represented mild to moderate soil pollution. So, soil pollution was critically enhanced after cultivation and irrigation. ER value of $\mathrm{Mn}$ was the highest (18.12) in Koiya soil before cultivation which indicated low ecological risk. However, all other sites also presented a low ecological risk. SPI values of As before cultivation varied from 4.03 to 4.68 and SPI values of As after harvesting ranged from 4.01 to 4.92 which specified moderate soil pollution. So, soil pollution is critically remained the same before and after cultivation and irrigation. The ER value of As was the highest in Mechaghona soil after harvesting (49.20) which indicated a moderate ecological risk. However, all other sites also presented a moderate ecological risk. This may due to sampling sites contained As bearing minerals. SPI values of $\mathrm{Ni}$ before cultivation varied from 2.51 to 3.85 which showed mild to moderate soil pollution and the SPI values of $\mathrm{Ni}$ after harvesting ranged from 3.17 to 3.82 which symbolized moderate soil pollution. So, the soil pollution was increased after cultivation and harvesting especially in Dhamalia and Mechaghona soil because before cultivation SPI was mild in both fields which converted to moderate SPI after harvesting. The ER value of Ni was the highest (21.22) in Gutudia soil after harvesting because Ni content in irrigation water of Koiya field was higher than other fields. However, all sampling sites represented a moderate ecological risk after cultivation. In terms of $\mathrm{Pb}$, SPI values were lower than other metals except for Koiya field. Koiya field showed moderate soil pollution. ER values also indicated that all the sampling sites presented a low ecological risk. This might due to irrigation water containing the lowest Pb concentration (Fig. 3). Status of ecological risk index (RI) was represented in Table 5. Rl analysis stated that all the sampling sites hold a moderate risk of heavy metals in soils. The highest RI (175.16) value was observed in Mehaghona soil after harvesting. The overall findings of RI indicated that soils were at potential risk of pollution. This might be due to an incremental application of agricultural inputs like pesticides, fungicides, adulterated fertilizers as well as irrigation water is also playing a potential factor for heavy metals load thus lead to heavy metal pollution in agricultural soil. 


\subsection{Heavy metal assessment in the grain samples}

As per Table 6, As concentration in all the samples didn't exceed the permissible limit [30]. The highest As content in rice grains $(0.53 \pm 0.05 \mathrm{mg} / \mathrm{kg})$ was observed in Dhamalia samples and the overall As content ranged between 0.27 to $0.53 \mathrm{mg} / \mathrm{kg}$. According to Hojsak et al. [31], the permissible limit of As in rice grains is $0.15 \mathrm{mg} / \mathrm{kg}$. Transfer factors of As ranged from 0.018 to 0.032 . Though transfer factor was comparatively lower, values of grain samples in the all sampling sites crossed the recommended limit and showed a great risk of As. Although Mn content was still below the permissible limit, its transfer factor was quite higher (0.059-0.156). In terms of $\mathrm{Ni}, \mathrm{Cu}$, and $\mathrm{Pb}$, metal concentrations in grain samples did not exceed the permissible limit as recommended by WHO/FAO [12] and Chiroma et al. [30]. But the transfer factor of $\mathrm{Ni}$ ranged from 0.071 to 0.148 and the TF of Cu ranged from 0.04 to 0.136 . So, it might be a concern in the future. However, a higher transfer factor means a higher risk of metal exposure. The lowest TF was found for $\mathrm{Pb}$ ranging from 0.002 to 0.008 which was a good indication for $\mathrm{Pb}$ accumulation in rice grain.

\section{Discussion}

$\mathrm{pH}$ and organic carbon content in soil have a potential influence on soil nutrient availability especially soil micronutrients and heavy metals mobility. In most of the cases, $\mathrm{pH}$ was insignificant with each other $(p<0.05)$, and neutral $\mathrm{pH}$ value enhanced the mobility of heavy metals [32]. In the study area, $\mathrm{pH}$ values showed an almost similar result before and after harvesting. This might be a possible reason for the increasing mobility of heavy metals. Organic carbon influenced to enhance the soil buffering capacity and helped to increase the mobility of metals [33]. Organic carbon content in soil was increased after harvesting. This might be the potential load of heavy metals in soils as well as crops.

In the study area, all the metals showed greater values than reference soil value and they are significantly varied from each other $(\mathrm{p}<0.05)$. Apart from that $\mathrm{Mn}, \mathrm{Ni}$, and $\mathrm{As}$ also exceeded the permissible limit [12]. According to Fig. 3, irrigation water contained more $\mathrm{Mn}$ concentration than that of other metals. This might be potential cause of Mn loading in the sampling area. Usually, As concentrations crossed the permissible value in all sampling areas that could be pointed as a potential causes of As contamination in the studied area. The same statement is also true for Ni contamination. But $\mathrm{Pb}$ concentration was observed relatively lower than that of other metals. This can be a reason for observing less $\mathrm{Pb}$ accumulation in the sampling areas. Iyaka and Kakulu [34] and Emurotu and Onianwa [35] carried a study in intensive agricultural soil to observe the heavy metal status and found the values within the permissible limit [12]. But Jia et al. [36] found higher heavy metals concentration in intensive farmland than the permissible limit. In their study, they found a huge application of agricultural inputs in the farmland that was the reason for increasing heavy metal load in the farmland area. So, agricultural inputs, as well as irrigation inputs play a vital role in heavy metal accumulation.

Ecological risk value of each heavy metal was decreasing order $\mathrm{Mn}>\mathrm{As}>\mathrm{Ni}>\mathrm{Pb}>\mathrm{Cr}$. Yao-guo et al. [37] conducted a study in polluted soil to evaluate the ecological risk and found a potential ecological risk of heavy metals as $\mathrm{Hg}>\mathrm{Cd}$ $>\mathrm{Pb}>\mathrm{Cu}>\mathrm{Cr}>\mathrm{As}>\mathrm{Zn}$. The overall $\mathrm{Rl}$ value stated that all the sampling sites were in a moderate level of contamination and the level of contamination was increased after harvesting. Chaoua et al. [38] stated that the contaminated irrigation water enhanced the load of heavy metals in soils and crops. Balkhair and Ashraf [39] also found the same results for both soils and crops. In our study, irrigation water contained a greater amount of $\mathrm{Mn}$ which might be a possible reason for accumulating higher amount of $\mathrm{Mn}$ in both soil and rice grain. The agrochemical input enhanced the potential load of heavy metals [37]. Wuana and Okieimen [40] also found that agrochemical inputs like pesticides, fertilizers, biosolids, and manures were the possible reason for increasing heavy metal concentration in soil. Atafar et al. [41] stated that $\mathrm{Cd}$, $\mathrm{Pb}$, and As content were significantly $(p<0.05)$ augmented after applying chemical fertilizers in the soil. A similar finding was also observed in the study of Nicholson et al. [42].

The transfer factor of $\mathrm{Mn}$ was higher in rice grain thus creating a chance for higher human consumption. Mn not only created a negative impact on human health but also induced plant function. Suresh et al. [43] observed that excess soil Mn disrupted stomatal function in two soybean cultivars. Mn also caused human lung injury like cough, bronchitis, pneumonitis along with damages lung [44]. As also showed significant transfer factor in rice grain. Exposure to As leads to cancer risk for millions of people $[45,46]$. In Bangladesh, rice was being cultivated by As-contaminated water thus lead to high As content in rice grain [47]. In our study, mostly groundwater was used for irrigation thus might be a possible reason for accumulating As at toxic level in rice grains. Other than that, all other metals demonstrated considerable transfer factors. Balkhair and Ashraf [39] observed a higher accumulation of heavy metals in okra plants. Sometimes 
transfer factors crossed the value of more than one because of applying wastewater for irrigation purposes. Due to the use of fresh groundwater for irrigation purposes, a comparatively lower transfer factor was observed in our study.

\title{
5 Conclusion
}

The heavy metals content was higher after harvesting than before cultivation in most cases. The concentration of major heavy metals in agricultural soil stated that the soil pollution index was higher for $\mathrm{Mn}$ in all experimental sites after harvesting. $\mathrm{Mn}$ and As also represented the moderate ecological risk especially Dhamalia soils showed the considerable $\mathrm{Mn}$ ecological risk after harvesting. Overall risk index depicted that all sampling sites were loading moderate risk of heavy metals thus should be taken into top consideration. In the analysis of rice grain, Arsenic (As) and Manganese (Mn) were also represented higher heavy metal accumulation, although As exceeded the recommended permissible limit. Irrigation water contained more As and $\mathrm{Mn}$ that might be a potential cause for heavy metal accumulation. Agricultural input might be another cause for heavy metal load although it was not analyzed in the study. However, this study creates a benchmark to the decision-makers about the current situation of major heavy metals load in the studied area and potential transfer to rice grain that helps them to take the further strategy for protecting heavy metals accumulation in the studied area. Hence regular monitoring and assessment are recommended to prevent the heavy metal's excessive build-up in the food chain.

Acknowledgements The authors wish to thank Soil, Water and Environment Discipline, Khulna University, and Asia Arsenic Network, Jashore, Bangladesh for providing all possible facilities during the research work.

\begin{abstract}
Author's contributions Md. Tareq Bin Salam initiated and supervised the whole work. Upoma Mahmud collected soil samples and rice grains from the field as well as compiled the whole work. Upoma Mahmud also wrote the manuscript and Md. Tareq Bin Salam corrected and improved the manuscript. Abu Shamim Khan and Md. Mizanur Rahman analyzed the samples in the laboratory and helped in the completion of the calculation. Finally, all authors read and approved the final manuscript.
\end{abstract}

Funding The research work was self-funded. No funding was available at any stages of the research.

Availability of data and materials All data generated or analyzed during this study are included in the article.

\section{Declarations}

Competing interests The authors declare that they have no competing interests.

Open Access This article is licensed under a Creative Commons Attribution 4.0 International License, which permits use, sharing, adaptation, distribution and reproduction in any medium or format, as long as you give appropriate credit to the original author(s) and the source, provide a link to the Creative Commons licence, and indicate if changes were made. The images or other third party material in this article are included in the article's Creative Commons licence, unless indicated otherwise in a credit line to the material. If material is not included in the article's Creative Commons licence and your intended use is not permitted by statutory regulation or exceeds the permitted use, you will need to obtain permission directly from the copyright holder. To view a copy of this licence, visit http://creativecommons.org/licenses/by/4.0/.

\section{References}

1. Wilson B, Pyatt FB. Heavy metal dispersion, persistence, and bioaccumulation around an ancient copper mine situated in Anglesey UK. Ecotoxilog Environ Saf. 2007;66:224-31. https://doi.org/10.1016/j.ecoenv.2006.02.015.

2. Türkdoğan MK, Kara FKK, Tuncer I, Uygan I. Heavy metals in soil, vegetables and fruits in the endemic upper gastrointestinal cancer region of Turkey. Environ Toxicol Pharmacol. 2003;13(3):175-9. https://doi.org/10.1016/S1382-6689(02)00156-4.

3. Sall ML, Diaw AKD, Gningue-Sall D, Aaron SE, Aaron JJ. Toxic heavy metals: impact on the environment and human health, and treatment with conducting organic polymers, a review. Environ Sci Pollut Res. 2020;27:29927-42. https://doi.org/10.1007/s11356-020-09354-3.

4. Islam MS, Ahmed MK, Al-Mamun MH, Islam SMA. Sources and ecological risks of heavy metals in soils under different land uses in Bangladesh. Pedosphere. 2019;29(5):665-75. https://doi.org/10.1016/S1002-0160(17)60394-1.

5. Salam MTB, Zaman SMS, Hossen SMT, et al. Consecutive 2-year data analysis to assess the soil quality and ecological risk of heavy metals in Tobacco field: a case study in Northern Bangladesh. SN Appl Sci. 2021;3:193. https://doi.org/10.1007/s42452-021-04152-z.

6. Rattan RK, Datta SP, Chhonkar PK, Suribabu K, Singh AK. Long term impact of irrigation with sewage effluents on heavy metal content in soils, crops and groundwater-a case study. Agricult Ecosyst Environ. 2005;109:310-22. 
7. Hossain M, Salam MTB. Changes in soil physio-chemical properties and fertility status of long-term cultivated soils in southwestern Bangladesh. Malay J Soil Sci. 2019;23:31-41. https://doi.org/10.26480/bda.01.2019.03.06.

8. Halim MA, Majumder RK, Zaman MN. Paddy soil heavy metal contamination and uptake in rice plants from the adjacent area of Barapukuria coal mine, northwest Bangladesh. Arab J Geosci. 2014;8:3391-401. https://doi.org/10.1007/s12517-014-1480-1.

9. McLaughlin MJ, Zarcinas BA, Stevens DP, Cook N. Soil testing for heavy metals, communications in soil science and plant. Analysis. 2000;31(11-14):1661-700. https://doi.org/10.1080/00103620009370531.

10. Kabata-Pendias A. Trace elements in soils and plants. 4th edn. Boca Raton: CRC Press; 2011. pp. 548. https://doi.org/10.1201/b10158.

11. Rudnick RL, Gao S. Composition of the continental crust. University of Maryland, College Park, MD, USA and China University of Geosciences, Wuhan, People's Republic of China. 2003. p. 110.

12. WHO/FAO (World Health Organization/Food and Agriculture Organization). Joint FAO/WHO/FAO, food standard programme codex alimentarius commission 13th session. Report of the thirty-eight session of the codex committee on food hygiene, Houston, USA. 2007, ALINORM 07/30/13.

13. Hasine MT, Huda ME, Khatun R, Saadat AHM, Ahasan M, Akter S, Uddin MF, Monika AN, Rahman MA, Ohiduzzaman M. Environment and Ecology Research. 2017;5(7):510-6. https://doi.org/10.13189/eer.2017.050707.

14. Ahmad MSA, Asraf M. Essential roles and hazardous effects of nickel in plants. Rev Environ Contam Toxicol Whitacre Ed. 2017;214:63-86.

15. Salam TB, Karmakar B, Hossain SMT, Robin MH, Mariam MZ, Hossain M. Agronomic performance of modern rice varieties in South-west Bangladesh. Plant Sci Today. 2019;6(4):528-32. https://doi.org/10.14719/pst.2019.6.4.632.

16. Ramadan MAE, Al-Ashkar EA. The effect of different fertilizers on the heavy metals in soil and tomato plant. Aust J Basic Appl. 2007;1:300-6.

17. Tembo BD, Sichilongo K, Cernak J. Distribution of copper, lead, cadmium and zinc concentrations in soils around Kabwe town in Zambia. Chemosphere. 2006;63(3):497-501. https://doi.org/10.1016/j.chemosphere.2005.08.002.

18. SRDI (Soil Resource Development Institute). Thana Nirdeshika Guide, developed by Ministry of Agriculture, Bangladesh. 2007.

19. Nelson DW, Sommers LE. Total carbon and soil organic matter. In: Methods of Soil Analysis. In: Sparks et al., editor Part 3-chemical methods. Madison, Wisconsin, USA: ASA-SSSA.1996. pp. 961-1010.

20. USDA (United States Department of Agriculture). Soil survey laboratory manual. Soil survey investigation report no.42, version 4.0, USDANRCS, Nebraska, USA. 2004. Publisher's Note: MDPI stays neutral with regard to jurisdictional claims in published maps and institutional affiliations.

21. Demirel S, Tuzen M, Saracoglu S, Soylak M. Evaluation of various digestion procedures for trace element contents of some food materials. J Hazard Mater. 2008;152:1020-6. https://doi.org/10.1016/j.jhazmat.2007.07.077.

22. Zang F, Wang S, Nan Z, Ma J, Zhang Q, Chen Y, Li Y. Accumulation, spatio-temporal distribution, and risk assessment of heavy metals in the soil-corn system around a polymetallic mining area from the Loess Plateau, northwest China. Geoderma. 2017;305:188-96. https:// doi.org/10.1016/j.geoderma.2017.06.008.

23. Hakanson L. An ecological risk index for aquatic pollution control-a sedimentological approach. Water Res. 1980;14:975-1001. https:// doi.org/10.1016/0043-1354(80)90143-8.

24. Wang Y, Yang L, Kong L, Liu E, Wang L, Zhu J. Spatial distribution, ecological risk assessment and source identification for heavy metals in surface sediments from Dongping Lake, Shandong. East China Catena. 2015;125:200-5. https://doi.org/10.1016/j.catena.2014.10.023.

25. Xia W, Wang R, Zhu B, Rudstam GL, Liu Y, Xu Y, Xin W, Chen Y. Heavy metal gradients from rural to urban lakes in central China. Ecol Process. 2020;9:47. https://doi.org/10.1186/s13717-020-00251-8.

26. Li QS, Chen Y, Fu H, Cui Z, Shi L, Wang L, Liu Z. Health risk of heavy metals in food crops grown on reclaimed tidal flat soil in the Pearl River estuary. China J Hazard Mater. 2012;227-228:148-54. https://doi.org/10.1016/j.jhazmat.2012.05.023.

27. Barałkiewicz D, Siepak J. Chromium, nickel and cobalt in environmental samples and existing legal norms. Pol J Environ Stud. 1999;8:201-8.

28. Alam MG, Snow ET, Tanaka A. Arsenic and heavy metal contamination of vegetables grown in Samta village, Bangladesh. Sci Total Environ. 2003;308:83-96. https://doi.org/10.1016/S0048-9697(02)00651-4.

29. Polizzotto ML, Lineberger EM, Matteson AR, Neumann RB, Badruzzaman ABM, Ali MA. Arsenic transport in irrigation water across rice-field soils in Bangladesh. Environ Pollut. 2013;179:210-7. https://doi.org/10.1016/j.envpol.2013.04.025.

30. Chiroma TM, Ebewele RO, Hymore FK. Comparative assessment of heavy metal levels in soil, vegetables and urban grey waste water used for irrigation in Yola and Kano. Intern Refere J Eng Sci. 2014;3(2):01-9.

31. Hojsak I, Braegger C, Bronsky J, Campoy C, Colomb V, Decsi T, Domellof M, Fewtrell M, Mis NF, Mihatsch W, Molgaard C, Goudoever JV. Arsenic in rice: a cause for concern. J Pediatr Gastroenterol Nutr. 2015;60(1):142-5. https://doi.org/10.1097/MPG.0000000000000502.

32. Mico C, Peris M, Sanchez J, Recatala L. Heavy metal content of agricultural soils in a Mediterranean semiarid area: the Segura River Valley (Alicante, Spain). Span J Agric Res. 2006;4(4):363-72. https://doi.org/10.5424/sjar/2006044-213.

33. McCauley A, Jone $\mathrm{C}$, Jacobsen J. Soil pH and organic matter. In: Nutrient management module no 8. 2009. http://landresources.monta na.edu/nm/documents/NM8.pdf. Accessed 10 Aug 2015.

34. Iyaka YA, Kakulu SE. Heavy metal concentrations in top agricultural soils around ceramic and pharmaceutical industrial sites in Niger State. Nigeria Res J Environ Earth Sci. 2012;4(2):171-6.

35. Emurotu JE, Onianwa PC. Bioaccumulation of heavy metals in soil and selected food crops cultivated in Kogi State, north central. Nigeria Environ Syst Res. 2017;6:21. https://doi.org/10.1186/s40068-017-0098-1.

36. Jia L, Wang W, Li Y, Yang L. Heavy metals in soil and crops of an intensively farmed area: a case study in Yucheng city, Shandong Province, China. Int J Environ Res Public Health. 2010;7:395-412. https://doi.org/10.3390/ijerph7020395.

37. Yao-guo WU, You-ning XU, Zhang J, Si-hai HU. Evaluation of ecological risk and primary empirical research on heavy metals in polluted soil over Xiaoqinling gold mining region, Shaanxi, China. Trans Nonferrous Metals Soc China. 2010;20(4):688-94. https://doi.org/10.1016/ S1003-6326(09)60199-0.

38. Chaoua S, Boussaa S, Gharmali AE, Boumezzough A. Impact of irrigation with wastewater on accumulation of heavy metals in soil and crops in the region of Marrakech in Morocco. J Saudi Soc Agric Sci. 2019;2019(18):429-36. https://doi.org/10.1016/j.jssas.2018.02.003.

39. Balkhair KS, Ashraf MA. Field accumulation risks of heavy metals in soil and vegetable crop irrigated with sewage water in western region of Saudi Arabia Saudi. J Biol Sci. 2015;23:32-44. https://doi.org/10.1016/j.sjbs.2015.09.023. 
40. Wuana AR, Okieimen FE. Heavy metals in contaminated soils: a review of sources, chemistry, risks and best available strategies for remediation international scholarly research network. ISRN Ecol. 2011;2011:402647. https://doi.org/10.5402/2011/402647.

41. Atafar Z, Mesdaghinia A, Nouri J, Homaee MJ, Yunesian M, Ahmadimoghaddam M, Mahvi AH. Effect of fertilizer application on soil heavy metal concentration. Environ Monit Assess. 2010;160:83-9. https://doi.org/10.1007/s10661-008-0659-x.

42. Nicholson FA, Smith SR, Alloway BJ. An inventory of heavy metals inputs to agricultural soils in England and Wales. Sci Total Environ. 2003;311(1-3):205-19. https://doi.org/10.1016/S0048-9697(03)00139-6.

43. Suresh R, Foy CD, Weidner JR. Effects of excess soil manganese on stomatal function in two soybean cultivars. J Plant Nutr. 1987;10(7):74960. https://doi.org/10.1080/01904168709363606.

44. Boojar MMA, Goodarzi FA. Longitudinal follow-up of pulmonary function and respiratory symptoms in workers exposed to manganese. J Occup Environ Med. 2002;44:282-90. https://doi.org/10.1097/00043764-200203000-00016.

45. Argos M, Kalra T, Rathouz PJ, Chen Y, Pierce B, Parvez F. Arsenic exposure from drinking water, and all-cause and chronic-disease mortalities in Bangladesh (HEALS): a prospective cohort study. Lancet. 2010;376:252-8. https://doi.org/10.1016/S0140-6736(10)60481-3.

46. Byrd DM, Roegner ML, Griffiths JC, Lamm SH, Grumski KS, Wilson R, Lai S. Carcinogenic risks of inorganic arsenic in perspective. Int Arch Occup Environ Health. 1996;68:484-94. https://doi.org/10.1007/BF00377874.

47. Williams PN, Islam MR, Adomako EE, Raab A, Hossain SA, Zhu YG. Increase in rice grain arsenic for regions of Bangladesh irrigating paddies with elevated arsenic in groundwater. Environ Sci Technol. 2006;40:4903-8. https://doi.org/10.1021/es060222i.

Publisher's Note Springer Nature remains neutral with regard to jurisdictional claims in published maps and institutional affiliations. 